\title{
Moderation of Back pain by Rehabilitation Exercises; Multifidus Muscle' Perspective
}

\author{
Qais Gasibat ${ }^{1}$, Nordin Bin Simbak* ${ }^{2}$ \\ ${ }^{1,2}$ Faculty of Medicine, Universiti Sultan Zainal Abidin
}

\begin{abstract}
Low back pain (LBP) is highly prevalent in our society and the multifidus muscle is the most important muscle for lumbar segment stability as per its relationship its atrophy and recurrences of low back pain besides, its recovery to normal size in patients undergone an exercise program resulting in stress, deterioration of the lumbar multifidus muscle tissue leading to impaired function. Nevertheless, particular important risk factor regarding low back pain is the weakness of multifidus muscle and conditioning of this muscle is connected with significant improvements on a chronic low back (CLBP), as well as with decreased useful disability. Strengthening of multifidus muscle can be helpful for preventing chronic low back pain $(C L B P)$. Beneficial exercises are wide use in the treatment of lower back pain. In this review, we have tried to list all the effective exercises for the low back pain $(L B P)$ to decrease pain and strengthening of multifidus muscles.
\end{abstract}

Keywords: Multifidus muscle; Low Back Pain; Rehabilitation exercises; strengthening of trunk muscles.

\section{Introduction}

Low back pain (LBP) is considered to be a common problem and it is largely thought of as a difficulty confined to Western countries nonetheless, since a long time an increasing amount of numerous reports demonstrated that low back pain is now a significant problem in Asian communities with a prevalence of low back pain (LBP) to be 28. 5\%. [29],[7],[47]. The lifetime prevalence of low back pain (LBP) was reported to be over 70 percent in industrialized countries [9], [48]. Many studies have shown that the multifidus is the most important muscle regarding lumbar segmental stability, with its origin in the posterior sacrum and superior iliac and it is inserted the spinous process of the vertebrae except cervical 1 (C1) and this muscle acts trunk lateral flexion and assists in trunk extension. Assistant muscles in trunk extension are multifidus, rotator, semispinalis, Interspinalis, and Stabilizers the hip extensor, especially in the prone lying. The nerve supply spinal nerve roots [40], [26], [42].

People who suffered from low back pain (LBP), have weaker trunk area muscles than healthy individuals. Therefore, trunk exercises are commonly recommended to patients with low back pain( LBP) [33], [3]. The lumbar multifidus muscle, which is thought to be particularly necessary for stability of lumber, the multifidus has demonstrated to be atrophied in different reports with infiltration of fats in patients with long-term low back pain (LBP) [12],[17],[18],[25],[28]. Besides the low back pain (LBP) another term referred to as chronic low back pain (CLBP) is sometimes defined as back pain that lasts for longer than 7-12 weeks. These pains cause the atrophy of the paraspinal, isolated multifidus, quadratus lumbar, psoas, and the gluteus maximus muscles to varying degrees, with most prominent in the multifidus to be affected [4],[10].A number of literature reviews and recommendations for the treatment of low back pain (LBP) indicate that exercise therapy constitutes an effective intervention with regard to patients with acute low back pain [21],[1],[16],[24], [5],[41],[6]. Exercise is safe for individuals suffering from back pain because it does not boost the risk of future back accidents or work absence [24]. However, providing positive effects in treating individuals with chronic low back pain (CLBP), despite the fact that, there is a lack of good proof for exercise therapy with regard to patients with acute low back pain, there are reports, that every patient with either severe or chronic low back pain (CLBP) might benefit from an appropriate specific exercise program [21].

The decrease in strength of trunk area muscles can be expected in persistent low back pain. Raising muscle strength can help in supporting the degenerative spine [23] and with reduced trunk muscle strength has been found to be directly related to chronic low back pain (CLBP), in addition, being overweight and decrease in trunk muscle mass, strength are important factors in chronic low back pain (LBP), along with a trunk muscle strengthening system to be helpful in reducing pain. Therefore, the majority of researchers has discovered that the trunk muscle strength is an important factor in chronic low back pain (CLBP) [13].

The actual association between trunk muscle mass, strength and low back pain (LBP) continues to be widely studied, but the reports are conflicting [39], besides to know that the strengthening of lumbar paraspinal 
muscles could be helpful for preventing chronic low back pain (CLBP) [32]. Probably, with stronger back muscle mass the risk of vertebral fractures will probably decrease [43]. There is absolutely no evidence that one exercise program is preferable to another for the rehabilitation associated with patients with low back pain (LBP). For that reason, a wide variety of exercises have been useful for a progressive strengthening of the lower back [21]. Electromyography (EMG) offers a means by which the back muscle mass activation levels can be examined during exercises, which can support a therapist in choosing appropriate exercises [21].

\section{Surface Electromyography}

Surface area Electromyography (SEMG) is a noninvasive technique for measuring muscle electrical activity that occurs during muscle mass contraction and relaxation process.

Surface area Electromyography is widely used in numerous applications, such as:

- Physical Rehabilitation (physical therapy/physiotherapy, kinesiotherapy chiropractic, and orthopaedics')

- Urology (treatment of incontinence)

- Function (sports training, motion evaluation, research)

- Ergonomics (studies in the workplace, job danger analysis, product design as well as certification) [49].

\section{Multifidus s' placement of electrode}

There was a study demonstrated good reliability in the use of surface electrodes for the lumbar multifidus [17]. Sites of electrode placement will be prepared by abrading the skin with fine sandpaper and cleaning the area with 70\% isopropyl alcohol. Excess hair will shave off whenever necessary [30].

In the lumbar multifidus muscle, the electrodes will be placed $2 \mathrm{~cm}$ laterally at the lumbosacral junction. Multifidus muscles at L5, 2cm laterally from the midline running through the L5 spinal process [17], [20], [11], [21], [50]. A reference electrode will be placed at the tip of the spinous process or on the posterior superior iliac spine process [30].Exercise program The exercises are usually performed 3 times with a hold for 5 seconds. Rest periods of 30 seconds is allowed between repetitions of the exercises and a 1-minute rest period will be given between exercises, the exercises will be persisted for 6 weeks occur twice a week [21],[46],[22].

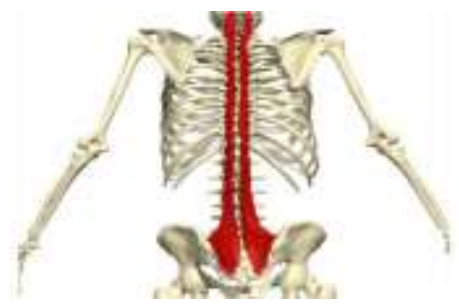

Fig A multifidus muscle

This review focuses on summarizing all the exercises for multifidus muscle profound in utilizing for the importance of function and decreasing the serenity of low back pain.

\begin{tabular}{|l|l|l|}
\hline Name of exercise & Perform & Reference \\
\hline Superman exercise (Fig 1) & $\begin{array}{l}\text { Lie down on your stomach with the } \\
\text { arms extended so that they are parallel } \\
\text { to the floor, palms down, slowly lift } \\
\text { your arms, upper body and legs from the } \\
\text { floor and hold for 5 seconds. }\end{array}$ & [38],[30],[21],[15],[35] \\
\hline Flying squirrel exercise (Fig 2) & $\begin{array}{l}\text { Lying prone with knees flexed, hips } \\
\text { internally rotated, and legs will be lifted } \\
\text { off the floor. Participants' arms will be } \\
\text { flexed at the elbows, shoulders } \\
\text { externally will be rotated, and lifted off } \\
\text { the floor. This position will hold for 5 } \\
\text { seconds. }\end{array}$ & \\
\hline $\begin{array}{l}\text { Prone trunk extension exercise (Fig } \\
\text { 3) }\end{array}$ & $\begin{array}{l}\text { Lie on your stomach and put your arms } \\
\text { behind your head, take your body up to } \\
\text { a fully extended position and you should } \\
\text { hold 5 seconds. Your legs should be } \\
\text { fully extended }\end{array}$ & [37], [21],[34],[11] \\
\hline Bridge exercise( Fig 4) & $\begin{array}{l}\text { Lie on your back with both legs bent, } \\
\text { tighten and squeeze your gluteus, lift } \\
\text { your butt off the floor hold on for 5 } \\
\text { seconds. }\end{array}$ & [21],[8],[15],[34] \\
\hline Bird dog exercise( Fig 5) & $\begin{array}{l}\text { On hands and knees with a neutral } \\
\text { spine, tense your abdominals and keep } \\
\text { your low back quiet, then reach way out }\end{array}$ & [21],[27],[34],[36],[31] \\
\hline
\end{tabular}




\begin{tabular}{|l|l|l|}
\hline & $\begin{array}{l}\text { with one hand, thumb up, and reach way } \\
\text { back with the opposite foot, pushing } \\
\text { through the heel, not the toes. }\end{array}$ & \\
\hline $\begin{array}{l}\text { Back bridge exercise with leg lift } \\
\text { (Fig 6) }\end{array}$ & $\begin{array}{l}\text { Lie on your back with your knees bent } \\
\text { and your feet flat on the floor, cross } \\
\text { your arms over your chest and raise the } \\
\text { lower half of your right leg until it's in } \\
\text { line with your left thigh, press your left } \\
\text { foot into the floor. }\end{array}$ & \\
\hline
\end{tabular}

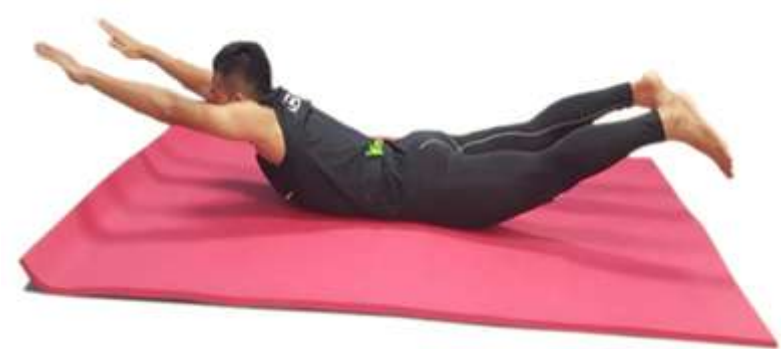

Superman exercise (Fig 1)

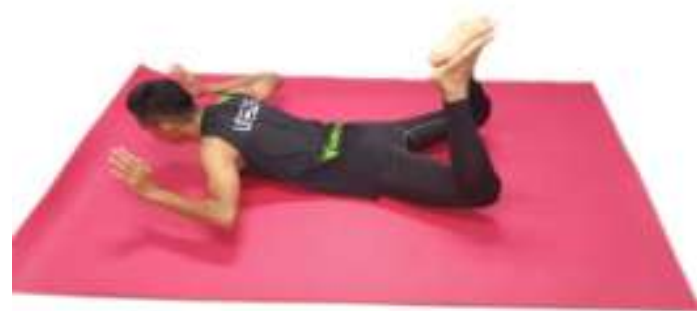

Flying squirrel exercise (Fig 2)

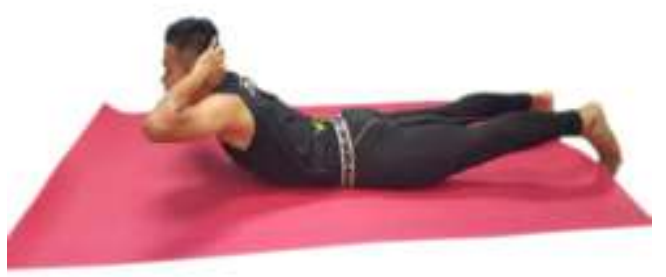

Prone trunk extension exercise (Fig 3)

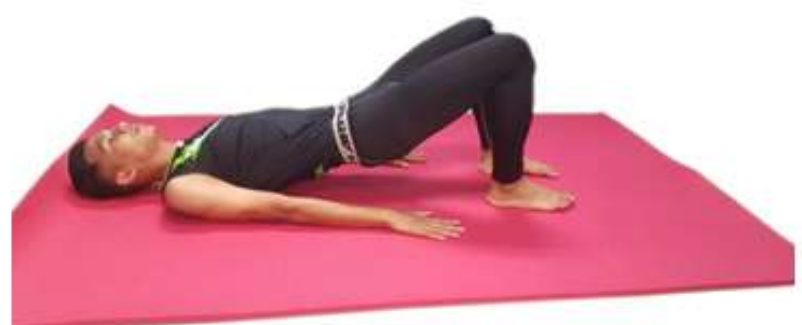

Bridge exercise (Fig 4)

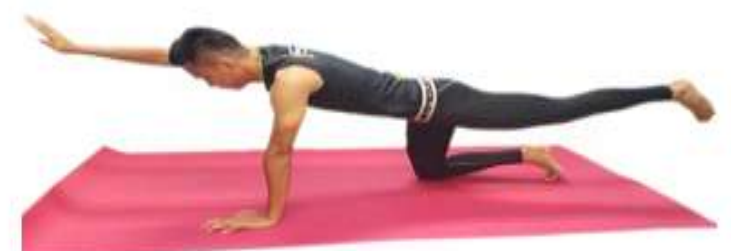

Bird dog exercise (Fig 5) 


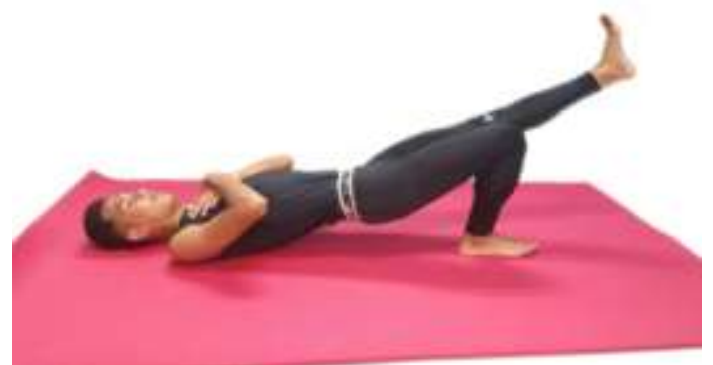

Back bridge exercise with leg lift (Fig 6)

\section{Conclusion}

The rehabilitation exercises which Found from the studies which had done before more appropriate than others to control as well as increase the multifidus muscle durability and this a study may be of great help for physical therapists in picking out exercises when progressing people with low back pain (LBP) from lowintensity exercises for those that require far more muscle activity. The surface electromyography (SEMG) can be used to identify the particular exercises which more appropriate to be able to strengthen muscles and handle pain.

\section{Acknowledgements}

I would like to thank physical therapy students at, University Sultan Zainal Abidin, Malaysia, for their assistance, I thank my family, for unconditional support and encouragement to pursue my interests, Last, but not least, I would be remiss if I did not thank Doctor Alhadi Jahan, who deserves credit for providing much needed assistance, and keeping my article running smoothly.

\section{Reference}

[1]. Abenhaim, L., Rossignol, M., Valat, J. P., Nordin, M., Avouac, B., Blotman, F., ... \& Vautravers, P. (2000). The role of activity in the therapeutic management of back pain: Report of the International Paris Task Force on Back Pain. Spine, 25(4S), 1S-33S.

[2]. Danneels, L. A., Vanderstraeten, G. G., Cambier, D. C., Witvrouw, E. E., De Cuyper, H. J., \& Danneels, L. (2000). CT imaging of trunk muscles in chronic low back pain patients and healthy control subjects. European Spine Journal, 9(4), $266-272$.

[3]. Gundewall, B., Liljeqvist, M., \& Hansson, T. (1993). Primary prevention of back symptoms and absence from work: a prospective randomized study among hospital employees. Spine, 18(5), 587-594.

[4]. Kamaz, M., Kiresi, D., Oguz, H., Emlik, D., \& Levendoglu, F. (2007). CT measurement of trunk muscle areas in patients with chronic low back pain. Diagnostic and interventional radiology, 13(3), 144.

[5]. Liddle, S. D., Baxter, G. D., \& Gracey, J. H. (2004). Exercise and chronic low back pain: what works?. Pain, 107(1), 176-190.

[6]. Rainville, J., Hartigan, C., Martinez, E., Limke, J., Jouve, C., \& Finno, M. (2004). Exercise as a treatment for chronic low back pain. The Spine Journal, 4(1), 106-115.

[7]. Chaiamnuay, P., Darmawan, J., Muirden, K. D., \& Assawatanabodee, P. (1998). Epidemiology of rheumatic disease in rural Thailand: a WHO-ILAR COPCORD study. Community Oriented Programme for the Control of Rheumatic Disease. The Journal of rheumatology, 25(7), 1382-1387.

[8]. Kendall FP, McCreary EK, Provance PG, Rodgers MM, Romani WA. 2005 .Muscles: Testing and Function With Posture and Pain. Baltimore, MD: Lippincott, Williams \& Wilkins.

[9]. Andersson, G. B. J. (1997). The epidemiology of spinal disorders. The adult spine: Principles and practice.

[10]. Arokoski, J. P., Kankaanpää, M., Valta, T., Juvonen, I., Partanen, J., Taimela, S., ... \& Airaksinen, O. (1999). Back and hip extensor muscle function during therapeutic exercises. Archives of physical medicine and rehabilitation, 80(7), 842-850.

[11]. Arokoski, J. P., Valta, T., Airaksinen, O., \& Kankaanpää, M. (2001). Back and abdominal muscle function during stabilization exercises. Archives of physical medicine and rehabilitation, 82(8), 1089-1098.

[12]. Barker, K. L., Shamley, D. R., \& Jackson, D. (2004). Changes in the cross-sectional area of multifidus and psoas in patients with unilateral back pain: the relationship to pain and disability. Spine, 29(22), E515-E519.

[13]. Bayramoglu, Meral, et al. "Isokinetic measurement of trunk muscle strength in women with chronic low-back pain." American journal of physical medicine \& rehabilitation 80.9 (2001): 650-655

[14]. BEIMBORN, D. S., \& MORRISSEY, M. C. (1988). A review of the literature related to trunk muscle performance. Spine, 13(6), 655-660.

[15]. Callaghan, J. P., Gunning, J. L., \& McGill, S. M. (1998). The relationship between lumbar spine load and muscle activity during extensor exercises. Physical therapy, 78(1), 8-18

[16]. Chou, R., Qaseem, A., Snow, V., Casey, D., Cross, J. T., Shekelle, P., \& Owens, D. K. (2007). Diagnosis and treatment of low back pain: a joint clinical practice guideline from the American College of Physicians and the American Pain Society. Annals of internal medicine, 147(7), 478-491.

[17]. Danneels, L. A., Cagnie, B. J., Cools, A. M., Vanderstraeten, G. G., Cambier, D. C., Witvrouw, E. E., \& De Cuyper, H. J. (2001). Intra-operator and inter-operator reliability of surface electromyography in the clinical evaluation of back muscles. Manual therapy, 6(3), 145-153.

[18]. Danneels, L. A., Vanderstraeten, G. G., Cambier, D. C., Witvrouw, E. E., De Cuyper, H. J., \& Danneels, L. (2000). CT imaging of trunk muscles in chronic low back pain patients and healthy control subjects. European Spine Journal, 9(4), 266-272 
[19]. Danneels, L. A., Vanderstraeten, G. G., Cambier, D. C., Witvrouw, E. E., Bourgois, J. D. W. D. C. H. J., Dankaerts, W., \& De Cuyper, H. J. (2001). Effects of three different training modalities on the cross sectional area of the lumbar multifidus muscle in patients with chronic low back pain. British journal of sports medicine, 35(3), 186-191.

[20]. Danneels, L., Coorevits, P., Cools, A., Vanderstraeten, G., Cambier, D., Witvrouw, E., \& De Cuyper, H. (2002). Differences in electromyographic activity in the multifidus muscle and the iliocostalis lumborum between healthy subjects and patients with subacute and chronic low back pain. European Spine Journal, 11(1), 13-19.

[21]. Ekstrom, R. A., Osborn, R. W., \& Hauer, P. L. (2008). Surface electromyographic analysis of the low back muscles during rehabilitation exercises. journal of orthopaedic \& sports physical therapy, 38(12), 736-745.not exercise,

[22]. França, F. R., Burke, T. N., Hanada, E. S., \& Marques, A. P. (2010). Segmental stabilization and muscular strengthening in chronic low back pain: a comparative study. Clinics, 65(10), 1013-1017.

[23]. Gordon, R., \& Bloxham, S. (2016, April). A Systematic Review of the Effects of Exercise and Physical Activity on Non-Specific Chronic Low Back Pain. In Healthcare (Vol. 4, No. 2, p. 22). Multidisciplinary Digital Publishing Institute.

[24]. Hayden, J., Van Tulder, M. W., Malmivaara, A., \& Koes, B. W. (2005). Exercise therapy for treatment of non- specific low back pain. The Cochrane Library.

[25]. Hodges, P., Holm, A. K., Hansson, T., \& Holm, S. (2006). Rapid atrophy of the lumbar multifidus follows experimental disc or nerve root injury. Spine, 31(25), 2926-2933.

[26]. Jenkins, G., \& Tortora, G. J. (2011). Anatomy and physiology. Wiley-Blackwell.

[27]. Kavcic, N., Grenier, S., \& McGill, S. M. (2004). Quantifying tissue loads and spine stability while performing commonly prescribed low back stabilization exercises. Spine, 29(20), 2319-2329.

[28]. Keller, A., Brox, J. I., Gunderson, R., Holm, I., Friis, A., \& Reikerås, O. (2004). Trunk muscle strength, cross-sectional area, and density in patients with chronic low back pain randomized to lumbar fusion or cognitive intervention and exercises. Spine, 29(1), 3-8.

[29]. Khan, A. A., Uddin, M. M., Chowdhury, A. H., \& Guha, R. K. (2014). Association of low back pain with common risk factors: a community based study. Indian J Med Res, 25, 50-55.

[30]. Kim, C. R., Park, D. K., Lee, S. T., \& Ryu, J. S. (2016). Electromyographic Changes in Trunk Muscles During Graded Lumbar Stabilization Exercises. $P M \& R, 8(10), 979-989$.

[31]. Koumantakis, G. A., Watson, P. J., \& Oldham, J. A. (2005). Trunk muscle stabilization training plus general exercise versus general exercise only: randomized controlled trial of patients with recurrent low back pain. Physical therapy, 85(3), 209-225.

[32]. Lee, H. I., Lee, S. T., Kim, M., \& Ryu, J. S. (2015). Sex differences in predicting chronicity of low-back pain after acute trauma using lumbar muscle area. American Journal of Physical Medicine \& Rehabilitation, 94(2), 123-130.

[33]. Lee, J. H., Hoshino, Y., Nakamura, K., Kariya, Y., Saita, K., \& Ito, K. (1999). Trunk Muscle Weakness as a Risk Factor for Low Back Pain: A 5- Year Prospective Study. Spine, 24(1), 54-57.

[34]. Luque-Suárez, A., Díaz-Mohedo, E., Medina-Porqueres, I., \& Ponce-García, T. (2012). Stabilization exercise for the management of low back pain. INTECH Open Access Publisher.

[35]. McGill, S. M. (1998). Low back exercises: evidence for improving exercise regimens. Physical therapy, 78(7), 754-765.

[36]. Monfort-Pañego, M., Vera-García, F. J., Sánchez-Zuriaga, D., \& Sarti-Martínez, M. Á. (2009). Electromyographic studies in abdominal exercises: a literature synthesis. Journal of manipulative and physiological therapeutics, 32(3), 232-244.

[37]. Okubo, Y., Kaneoka, K., Imai, A., Shiina, I., Tatsumura, M., Izumi, S., \& Miyakawa, S. (2010). Electromyographic analysis of transversus abdominis and lumbar multifidus using wire electrodes during lumbar stabilization exercises. journal of orthopaedic \& sports physical therapy, 40(11), 743-750.

[38]. Oliver, G. D., Stone, A. J., \& Plummer, H. (2010). Electromyographic examination of selected muscle activation during isometric core exercises. Clinical Journal of Sport Medicine, 20(6), 452-457.

[39]. Paalanne, N. (2011). Postural balance, isometric trunk muscle strength and low back symptoms among young adults (Doctoral dissertation,

[40]. Patton, K. T. (2015). Anatomy and physiology. Elsevier Health Sciences.

[41]. Pengel, H. M., Maher, C. G., \& Refshauge, K. M. (2002). Systematic review of conservative interventions for subacute low back pain. Clinical rehabilitation, $16(8), 811-820$

[42]. Saladin, K. S. (1998). Anatomy \& physiology. WCB/McGraw-Hill.

[43]. Sinaki, M., Wollan, P. C., Scott, R. W., \& Gelczer, R. K. (1996, October). Can strong back extensors prevent vertebral fractures in women with osteoporosis?. In Mayo Clinic Proceedings (Vol. 71, No. 10, pp. 951-956). Elsevier.

[44]. Stevens, V. K., Vleeming, A., Bouche, K. G., Mahieu, N. N., Vanderstraeten, G. G., \& Danneels, L. A. (2007). Electromyographic activity of trunk and hip muscles during stabilization exercises in four-point kneeling in healthy volunteers. European Spine Journal, 16(5), 711-718.

[45]. Stevens, V. K., Vleeming, A., Bouche, K. G., Mahieu, N. N., Vanderstraeten, G. G., \& Danneels, L. A. (2007). Electromyographic activity of trunk and hip muscles during stabilization exercises in four-point kneeling in healthy volunteers. European Spine Journal, 16(5), 711-718.

[46]. Stone, W. J., \& Coulter, S. P. (1994). Strength/Endurance Effects From Three Resistance Training Protocols With Women. The Journal of Strength \& Conditioning Research, 8(4), 231-234.

[47]. Tomita, S., Arphorn, S., Muto, T., Koetkhlai, K., Naing, S. S., \& Chaikittiporn, C. (2010). Prevalence and risk factors of low back pain among Thai and Myanmar migrant seafood processing factory workers in Samut Sakorn Province, Thailand. Industrial health, 48(3), 283-291.

[48]. Van Tulder, M., Becker, A., Bekkering, T., Breen, A., Gil del Real, M. T., Hutchinson, A., ... \& Malmivaara, A. (2006). Chapter 3 European guidelines for the management of acute nonspecific low back pain in primary care. European spine journal, 15, s169s191.

[49]. Florimond, V. (2009). Basics of surface electromyography applied to physical rehabilitation and biomechanics. Montreal, Canada: Thought Technology Ltd.

[50]. Biedermann, H. J., Shanks, G. L., Forrest, W. J., \& Inglis, J. (1991). Power Spectrum Analyses of Electromyographic Activity: Discriminators in the Differential Assessment of Patients with Chronic Low-Back Pain. Spine, 16(10), 1179-1184. 